\title{
POTENSI BAKTERI KITINOLITIK Lysinobacillus fusiformis SEBAGAI BIOKONTROL TERHADAP CENDAWAN PATOGEN TANAMAN JAGUNG (Zea Mays)
}

\author{
Eka Sukmawaty $^{1 *}$, Mashuri Masri ${ }^{1}$, Siti Patima ${ }^{1}$ \\ ${ }^{1}$ Jurusan Biologi Fakultas Sains dan Teknologi \\ Universitas Islam Negeri (UIN) Alauddin Makassar \\ *email: Ekasukmawaty@uin-alauddin.ac.id
}

\begin{abstract}
Abstrak: Bakteri kitinolitik merupakan bakteri yang mebghasilkan kitinase yang berpotensi digunakan sebagai agen biokintrol pada cendawan patogen. Penelitian ini bertujuan untuk melihat kemampuan bakteri Lysnibacillus fusiformis dalam menghambat pertumbuhan cendawan patogen dari tanaman jagung (Zea mays). Cendawan patogen diisolasi dari tanaman jagung yang menunjukkan gejala infeksi cendawan dan diidentifiaksi sampai tingkat genus dengan buku manual identifikasi cendawan. Kemampuan penghamabatan bakteri $L$. fusiformis dijuji dengan metode dual culture. Hasil penelitain menunjukkan terdapat dua genus cendawan patogen yang diperoleh yaitu Rhizopus dan Fusarium. Bakteri L. fusiformis mampu menghambat pertumbuhann kedua cendaan dengan persen aktivitas masing $100 \%$ dan $90,9 \%$.
\end{abstract}

Kata Kunci: Bakteri kitinolitik, Lysnibacillus fusiformis, Biokontrol, Cendawan patogen.

\section{PENDAHULUAN}

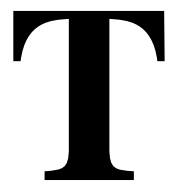

anaman jagung merupakan salah satu komoditas palawija utama di Indonesia. Selain sebagai bahan baku pangan manusia juga menjadi sumber pakan ternak serta bahan industry lainnya (Kurniati, 2012).

Kandungan jagung terdiri atas $70 \%$ pati, $10 \%$ protein, dan $5 \%$ lemak, bahan baku pakan ternak $46 \%$ dari komposisinya berasal dari jagung (Sondakh, Rauf dan Rembang, 2016). Jagung merupakan salah satu sereal paling penting untuk konsumsi manusia dan hewan dalam bentuk produk makanan dan produk turunan lainnya (Idris dan Ali 2015).

Komoditas jagung dapat dikonsumsi oleh masyarakat dalam berbagai bentuk olahan, tidak hanya sebagai pangan pokok namun juga sebagai lauk-pauk, 
makanan selingan, dan bahan setengah jadi yang dihasilkan oleh beragam jenis industri dan skala usaha. Sebagai usaha dalam memenuhi kebutuhan jagung, tidak kurang dari 10 juta petani melakukan usaha tani komoditas jagung. (Suriani dan Muis, 2016).

Namun pengembangan produktivitas hasil pertanian jagung mengalami berbagai kendala antara lain rendahnya harga jual jagung di tingkat petani karena tidak adanya standar harga, karena petani belum melakukan budidaya jagung secara optimal dan perawatan intensif untuk pengendalian hama dan penyakit. Hal ini menyebabnkan petani menjual produk jagungnya kepada tengkulak dengan harga murah dibandingkan harus menanggung kerugian karena kerusakan tanaman (Sujarwo, Anindita dan Pratiwi, 2011).

Kerusakan tanaman budi daya jagung salah satunya dihadapkan pada penyakit tanaman, antara lain yang disebabkan oleh cendawan patogen yang dapat menurunkan produksi, seperti Fusarium spp. Cendawan patogen ini menyebabkan pembusukan pada batang, tongkol, dan biji jagung. Beberapa spesies Fusarium yang ditemukan merusak pada tanaman jagung di antaranya $F$. oxysforum, $F$. verticillioides dan $F$. polidonogeum (Eller et al, 2008). Cendawan patogen lainnya yang menyerang tanaman agung yaitu cendawan Rhizoctonia solani (Soenartiningsih, 2005) dan Puccinia polysora (Aditya, Hasanuddin dan Pinem 2013).

Upaya pengendalian yang telah dilakukan selama ini di antaranya penggunaan varietas tahan, eradikasi, dan aplikasi pestisida kimia. Penggunaan pestisida kimia mampu menurunkan serangan cendawan patogen pada jagung namun terdapat beberapa dampak negatif yang ditimbulkan (Strobel dan Daisy, 2003).

Oleh karena itu upaya penanggulangan cendawan patogen dewasa banyak menggunakan bakteri antagonis khususnya bakteri kitinolitik. Wibowo dkk (2017) menemukan bahwa terdapat 10 galur bakteri kitinilotik yang berpotensi menghambat pertumbuhan hifa Ganoderma boninense setelah diuji antagonis. Bacillus sp. BK17 telah dilaporkan mampu menghambat dan mengendalikan pertumbuhanan S. rolfsii dan F. Oxysporum (Hutauruk, dkk 2016). 


\section{BAHAN DAN METODE}

\section{Isolasi cendawan patogen}

Eksplan tanaman jagung yang terkena gejala penyakit dan memotong dengan ukuran $2 \times 2 \mathrm{~mm}$ dan disterilisasi dengan alkohol 70\%. diletakkan diletakkan pada PDA, diinkubasi selama 3-7 hari. Biji jagung langsung disterilisasi dengan alkohol $70 \%$ dan dibilas dengan aquades steril kemudain diletakkan pada media PDA. Cendawan yang tumbuh dari potongan daun, batang, akar dan biji pada media PDA diamati setiap hari. Pada saat pertumbuhan hifa sudah mencapai $2-3 \mathrm{~cm}$ diambil untuk mendapatkan biakan murni.

\section{Identifikasi cendawan patogen}

Identifikasi cendawan dilakukan secara makroskopik dan mikroskopik. Untuk identifikasi makroskopis diamati ciri-ciri pertumbuhan koloninya. Sedangkan untuk pengamatan mikrosokopis dilakukan dengan meletakkan selotip secara perlahan pada permukaan media yang ditumbuhi cendawan patogen kemudian dipindahkan pada kaca preparat yang telah diberi methylen blue. Cendawan patogen diamati di bawah mikroskop dan didentifikasi jenis cendawan tersebut menggunakan buku identifikasi Barnett and Hunter (1998).

\section{Uji antagonis bakteri kitinolitik terhadap cendawan patogen}

Cendawan patogen ditanam di bagian tengah media NA setelah itu menggoresan melintang bakteri kitinolitik dengan jarak $3 \mathrm{~cm}$ dari cendawan yang telah ditanam sebelumnya, menutup dan menyegel cawan petri dan menyimpannya dalam suhu ruang selanjutnya mengamati hingga hari ke tujuh, persentase aktivitas bakteri kitinolitik terhadap cendawan patogen dihitung menggunakan rumus $\mathrm{AFA}=G C-G T / G C-A X 100 \%$ (Mori et al., 1997 dalam Novriyanti et al., 2010).

\section{HASIL DAN PEMBAHASAN}

Berdasarkan hasil isolasi dari bagian tanaman jagung yang terinfeksi cendawan patogen ditemukan 5 isolat berbeda berdasarkan pengamatan morfologi 
secara makroskopis warna dan type hifa cendawan.

Identifikasi cendawan patogen pada organ pelepah, daun, biji dan bunga pada tanaman jagung secara makroskopis dalam media PDA dan secara mikroskopis meliputi pengamatan bentuk, warna konidia, hifa serta ada tidaknya sekat pada hifa ditemukan 2 genus cendawan patogen penyebab kerusakan pada tanaman jagung yaitu Fusarium dan Rhizopus ,dapat dilihat pada Tabel 1. Identifikasi juga dilakukan dengan pengamatan mikrosokopis hifa dan konidia. Hasil pengamatan makrokopis dan mikroskopis kelima isolate cendawan tersebut dikonfirmasi dengan buku identifikasi Barnett dan Hunter.

Tabel 1. Hasil identifikasi cendawan patogen tanaman jagung (Zea mays)

\begin{tabular}{|c|c|c|}
\hline No & Kode Isolat & Genus cendawan \\
\hline 1 & CM 1 & Fusarium \\
2 & CM 2 & Fusarium \\
3 & CM 3 & Rhizopus \\
4 & CM 4 & Rhizopus \\
5 & CM 5 & Rhizopus \\
\hline
\end{tabular}

Pengamatan makroskopis Rhizopus meliputi warna permukaan dan balik koloni berwarna coklat kehitaman dengan tekstur koloni hifa halus pendek dan tegak, secara keseluruhan sering transparan. Tekstur cendawan pada pengamatan tersebut memiliki penonjolan seperti kancing di bagian tengah koloni, tidak adanya tetesan eksudat, garis radial maupun lingkaran konsentris.

Menurut Dwidjoseputro (1981) cendawan patogen Rhizopus sp. merupakan golongan cendawan dengan kelas Zygomycetes yang memiliki ciri-ciri miselium berbentuk tabung panjang tanpa sekat-sekat dan berwarna abu-abu kehitaman. Miselium Rhizopus sp. terbagi-bagi atas stolon yang menghasilkan rhizoid dan sporangiofor. Rhizopus memiliki karakteristik yang dapat membentuk koloni dengan cepat, membentuk stolon dan rhizoid, dimana pertumbuhan cabang rhizoid pada media berkebalikan dengan sporangiofor.

Sedangkan hasil pengamatan makroskopis Fusarium meliputi Fusarium sp. di atas didapatkan bahwa warna permukaan dan balik koloni berwarna putih abu-abu dengan tekstur koloni hifa halus pendek dan tegak, secara keseluruhan sering transparan. Tekstur cendawan berupa rugose yaitu koloni yang memiliki 
alur-alur yang ketinggiannya tidak beraturan dan tampak garis-garis radial dari reverse side, tidak adanya tetesan eksudat, garis radial tetapi memilikii lingkaran konsentris.

Suryanto, Patonah dan Munir (2010) menjelaskan gejala awal yang terjadi pada tumbuhan jagung yang terserang cendawan patogen Fusariun pada awalnya tumbuhan tersebut m layu pada bagian daun lama kelamaan akan menguning berubah menjadi coklat dan rapuh. Di bagian daun akan terlihat kumpulan hifa berwarna putih yang akan menyebar ke bagian pelepah hingga batang sehingga jaringan yang terkena cendawan patogen akan mengalami pembusukan. Diketahui bahwa jika Fusarium spp. yang menyerang tanaman jagung sangat sukar dikendalikan karena kemampuannya bertahan dalam tanah selama bertahun-tahun dengan cara membentuk spora meskipun kondisi lingkungan yang tidak memungkinkan (Sudantha, 2010).

Cendawan patogen yang berhasil diisolasi kemudian diuji antagonis dengan bakteri kitinolitik Lysinobacills fusiformis. Hasil uji antagonis dilihat setelah hari ke tujuh inkubasi (Gambar 1) yang memperlihatkan bahwa bakteri $L$. fusiformis mampu menghambat pertumbuhan ke lima isolate cendawan patogen dengan persen aktivitas yang tinggi (Tabel 1). Tingginya persen aktivitas bakteri iini memnandakan bahwan bakteri L. fusiformis berpotensi dijadikan sebagai agen pengendali hayati.

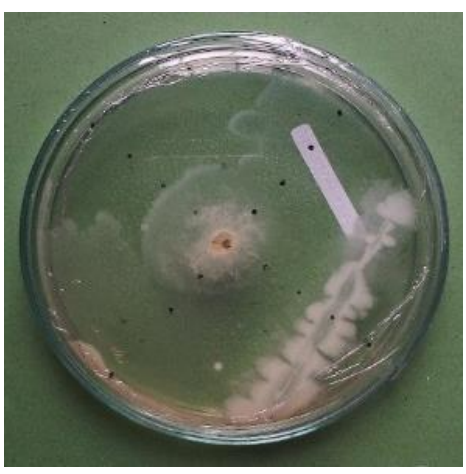

A

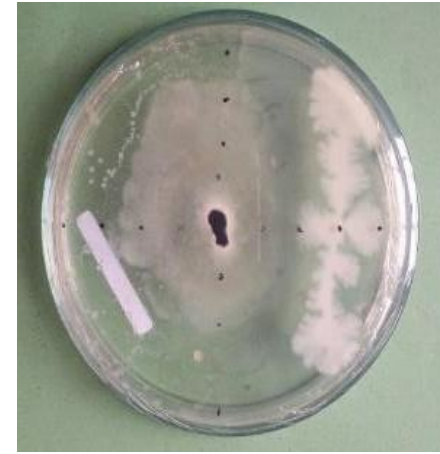

B

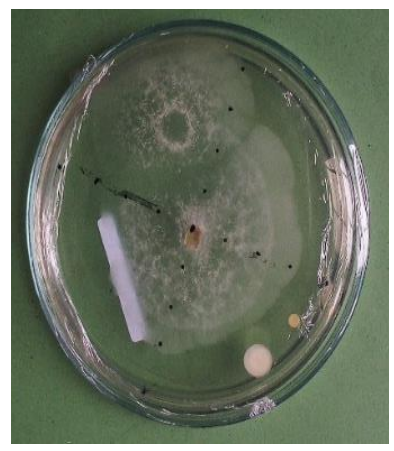

C

Gambar 1. (a) L. fusiformis terhadap Rhizopus sp. (b) L. fusiformis terhadap Fusarium sp. (c) Kontrol Rhizopus sp. pada media Nutrient Agar 
Tingginya aktivitas penghambatan bakteri L. fusiformis terhadap kedua cendawan ini disebakan karena aktivitas enzim kitinolitik bakteri ini. Diketahui bahwa dinding sel cendawan tersusun atas kitin yang dapat dihidrolisi oleh kitinase. semakin besar zona hambat yang dihasilkan dari aktivitas enzim maka semakin banyak enzim yang dihasilkan pada proses hidrolisis kitin oleh bakteri terhadap cendawan patogen (Tronsmo and Herman, 1993).

Tabel 2. Persentase Aktivitas L. fusiformis terhadap cendawan patogen

\begin{tabular}{|c|l|c|}
\hline $\begin{array}{c}\text { Bakteri } \\
\text { kitinolitik }\end{array}$ & $\begin{array}{c}\text { Cendawan } \\
\text { patogen }\end{array}$ & $\begin{array}{c}\text { Persentase aktivitas anti jamur } \\
\text { (\%AFA) }\end{array}$ \\
\hline \multirow{2}{*}{ L. fusiformis } & Rhizopus $\mathrm{sp}$. & $100 \%$ \\
\cline { 2 - 3 } & Fusarium $\mathrm{sp}$. & $90,9 \%$ \\
\hline
\end{tabular}

Meskipun L. fusiformis menunjukkan persentase aktivitas yang tinggi pada kedua cendawan, namun terdapat perbedaan besar pesentase. Pada tabel bisa dilihat bahwa L. fusiformis menunjukkan persentasi yang lebih rendah pada cendawan Fusarium sp. Cendawan Fusarium sp. lebih tahan terhadap enzim kitinase yang dihasilkan oleh bakteri L. fusiformis karena komposisi dinding selnya berbeda dengan cendawan Rhizopus sp. Komposisi dinding sel cendawan dari Fusarium sp. pada lapisan luar terdapat senyawa glikoprotein yang dapat melindungi permukaan miselium (Schoffelmeer, Klis and Cornelissen, 1999).

Enzim kitinase pada bakteri kitinolitik menghidrolisis senyawa polimer kitin yang menjadi penyusun utama dinding sel dari cendawan patogen menjadi oligosakarida atau monomer $\mathrm{N}$-asetil glukosamin dengan cara menghidrolisis kitin secara acak pada ikatan glikosidik. Enzim kitinase yang dibedakan berdasarkan cara kerjanya dalam mendegradasi kitin, yaitu eksokitinase, endokitinase, dan Nasetil glukosamidase. Eksokitinase bekerja memotong polimer kitin hanya dari ujng nonreduksi. Endokitinase memotong polimer kitin secara acak dan menghasilkan dimer, trimer, tetramer dan oligomer gula. $\mathrm{N}$-asetil glukosamidase yang memutuskan diasetilkitibiosa dan menghasilkan $\mathrm{N}$-asetilglukosamin (Rachmawati, Tius dan Yuninda 2015). 
Kitinase telah digunakan dalam bidang pertanian sebagai agen biokontrol terhadap hama serangga dan cendawan patogen yang memiliki komponen kitin pada dinding sel. Sebagai agen biokontrol, enzim kitinase dan protease berperan pada proses pendegradasi cendawan patogen dengan mekanisme mendegradasi dan melisiskan dinding sel cendawan. Setelah cendawan tersebut mati, mikroba kitinolitik akan berkembang biak dan menggunakan nutrisinya (Ahmad R.Z. 2007).

\section{KESIMPULAN}

Dari hasil penelitian dapat disimpulkan bahwa bakteri Lysinobacillus fusiformis berpotensi digunakan sebagai agen biokontrol cendawan patogen tanaman jagung yang terdiri atas genus Rhizopus dan Fusarium dengan penghambatan masing-masing $100 \%$ dan $90,9 \%$.

\section{DAFTAR PUSTAKA}

Ahmad R.Z. "Aktivitas Enzim Kitinase dan Protease Pada Cendawan Nematofagus (Duddingtonia flagrans Dan Saccharomyces cereviseae)". Seminar Nasional Teknologi Peternakan dan Veteriner (2007).

Barnett, H. L, and Hunter, B. B. Illustrated Genera of Imperfect Fungi. Minneapolis: Burgess Publ. Co 1998.

Dwidjoseputro. Dasar-dasar Mikrobiologi, Bandung: Penerbit Alumni, 1978.

Eller, M. S., Robertson, L. A., Payne, G.A., Holland, J. B. "Grain yield and Fusarium ear rot of maize hybrids developed from lines with varying levels of resistance". Maydica 53 no.1 (2008): p.231-237.

Hutauruk, D., Suryanto, D., Munir, E. “Asai Isolat Bakteri Kitinolitik Bacillus Sp. Bk17 Pada Media Pembawa Tanah Gambut Dan Kompos Xxx janjang Kelapa Sawit Dalam Menghambat Pertumbuhan Jamur Patogen Sclerotium Rolfsii Dan Fusarium Oxysporum Pada Kecambah Cabai”. J. Hpt Tropika 16 no. 1 (Maret 2016): h. 61-70.

Idris, Y.A., Ali, S.A.M. "Response of maize (Zea mays L.) To Sodium Chloride concentrations at early growth stages Y. Department of Agronomy, Faculty Of Agriculture, University Of Zalingei”. International Journal Of Agronomy And Agricultural Research 6 no. 4 (April 14, 2015): p. 68-74. 
Eka Sukmawaty dkk, Potensi Bakteri Kitinolitik Lysinobacillus fusiformis ..._ 175

Novriyanti, E., Santosa, E., Syafii, W., Turjaman, M., Sitepu, I.R. "Antifungal Activity Of Wood Extract Of Aquilaria Crassna Pierre Ex Lecomte Against Agarwood-inducing Fungi, Fusarium solani". Journal od Forestry Research 7 no. 2 (2010): p. 155-165

Rachmawaty S. P., Tius, S. E., Yuninda, K. W. "Enzim Kirinase dan Aplikasi di Bidang Industri”. Chitinase and Aplication 3 no. 3 (2015): h. 878-887.

Schoffelmeer, E. A. M., Klis, F. M., Cornelissen, B. J. C. "The Cell Wall Of Fusarium oxifinarum". Fungal Ganet Biol 27 (1999): p. 275-285.

Strobel, G. A., Daisy, B. "Bioprospecting For Microbial Endophytes And Their Natural Products". Microbiol Mol Biol 67 no. 4 (2003): p. 491-502.

Soenartiningsih., Fatmawati, Adnan, A. M. "Identifikasi Beberapa Penyakit Utama Pada Tanaman Sorgum Dan Jagung Di Sulawesi Tengah". Balai Penelitian Tanaman Serealia. Seminar Nasional Serealia (2013): h .420432.

Sudantha, I. M. "Pengujian beberapa jenis jamur endofit dan saprofit Trichoderma spp. terhadap penyakit layu fusarium pada tanaman kedelai". Jurnal Agroteksos 20 no.2 (2010): h. 90-102.

Sujarwo, R. Anindita, Dan T. I. Pratiwi. “Analisis Efisiensi Pemasaran Jagung (Zea Mays L.) Studi Kasus Di Desa Segunung, Kecamatan Dlanggu, Kabupaten Mojokerto”. Jurnal AGRISE 11 no. 1 (2011): p. 56 - 64.

Suriani., Muis, A. "Fusarium Pada Tanaman Jagung Dan Pengendaliannya Dengan Memanfaatkan Mikroba Endofit”. Iptek Tanaman Pangan 11 no. 2 (2016): h. 133-142.

Tronsmo, A., Herman, G.E., Anal, Biochem, 2 